Research

\title{
Characterization of canine
}

\section{mastocytoma cell response to cryoablation}

\author{
Kimberly L Santucci ${ }^{1}$, Kristi K Snyder ${ }^{1}$, Robert G Van \\ Buskirk $^{1-3}$, John G Baust ${ }^{2,3}$ and John M Baust ${ }^{1 *}$ \\ ${ }^{1}$ CPSI Biotech, Owego, NY, USA \\ ${ }^{2}$ Center for Translational Stem Cell and Tissue Engineering Binghamton University, 4400 Vestal \\ Parkway East, Binghamton, NY 13902, USA \\ ${ }^{3}$ Department of Biological Sciences, Binghamton University, 4400 Vestal Parkway East, Binghamton, \\ NY 13902, USA
}

Received: 20 December, 2019

Accepted: 31 January, 2020

Published: 04 February, 2020

*Corresponding author: John M Baust, CPSI Biotech, 2 Court St. Owego, NY 13827, USA, Tel: (607) 687-8701; Fax: 607-348-1516;

E-mail: jmbaust@cpsibiotech.com

https://www.peertechz.com

Check for updates

\section{Abstract}

Introduction: Mastocytoma Tumors (MCT) represent $16 \%-21 \%$ of all skin cancers in dogs, making it the most common form of cutaneous cancer. Solitary MCT are typically treated with wide surgical excision margins. While effective, MCT excision can cause the release of a large amount of histamine and other cytokines resulting in complications such as systemic shock or anaphylaxis. Treatments such as chemotherapy and radiotherapy have been considered to achieve complete remission. Cryoablation also represents a potential treatment option for MCT. While studies have shown cryoablation to be beneficial for the treatment of numerous cancers in animals and humans, few studies have described the use of cryoablation to treat MCT's. The limited use of cryoablation is due to a number of factors including a lack of basic information pertaining to dosing (minimal lethal temperature) necessary to destroy MCT cancer. As such, in this study we conducted a series of in vitro studies using the $\mathrm{C} 2$ cell line and a pilot ex vivo fine needle aspirate tissue sample in an effort to detail the effects of freezing of canine MCT.

Methods: Samples were exposed to temperatures ranging from $-5^{\circ} \mathrm{C}$ to $-25^{\circ} \mathrm{C}$, modeling the periphery of a cryogenic lesion for 3,5 and 10 minutes, and various markers of viability and modes of cell death were assessed daily over a 3 days recovery period. Additionally, investigation of the involvement of apoptosis in MCT cell death flowing freezing was conducted via immunoblotting and caspase inhibition studies.

Results: Viability studies revealed the $-25^{\circ} \mathrm{C}$ isotherm as the critical minimal lethal temperature to achieve complete $\mathrm{MCT}$ cell death regardless of hold time. As the hold time at temperatures of $-15^{\circ} \mathrm{C}$ and $-20^{\circ} \mathrm{C}$ increased from 3 to 10 minutes the level of cell death was also found to increase. Fluorescence microscopy, caspase inhibition and protein analysis revealed necrosis to be the primary mode of cell death following freezing. These studies, however, also revealed a significant level of apoptotic cell death post-freeze. Molecular analysis suggested that freezing to $-15^{\circ} \mathrm{C}$ to $-20^{\circ} \mathrm{C}$ resulted in the activation of mitochondrial mediated apoptosis 4 to 8 hours post freeze.

Conclusions: In summary, this in vitro study was designed as a first step investigation into the sensitivity of MCT cancer to freezing. These in vitro results suggest that freezing to temperatures of $\leq-20^{\circ} \mathrm{C}$ results in a high degree of MCT cell destruction. Further the data suggest that both apoptosis and necrosis play an important role in cell death following cryoablation. These data may have translational application to MCT treatment in vivo.

\section{Introduction}

Mastocytoma represents $16 \%-21 \%$ of all skin cancers in dogs, making it the most common form of cutaneous cancer [1]. Mast cells are generated from hematopoietic stem cells, reside in connective tissues, and comprise a necessary component of the immune response system [2]. The cause of mast cell tumors (MCT's), whether benign or malignant, is unknown. The formation of cancerous MCT's occurs frequently in dogs with median age of onset between 8-9 years [3,4]. One of the most predictive factors in MCT development and subsequent aggressiveness is breed. The majority of reports agree that boxers, Labrador retrievers, pugs, golden retrievers and bulldog breeds present with the highest incidence of MCT's [3-7]. Though there are a number of factors which can influence prognosis, including breed, c-kit mutation status and age, many veterinarians agree that the most predictive factor in MCT aggressiveness is tumor grade. Though there 
can be wide variability in the physical appearance of cutaneous MCT's, grade I tumors are often surgically excised with small margins for successful outcome, while grade II and III tumors can present a greater challenge. In general, a solitary MCT with wide surgical excision margins carries a positive prognosis. However, the surgical excision can cause the release of a large amount of histamine and other cytokines which may result in complications such as systemic shock or anaphylaxis [8]. Additionally, in some cases, wide surgical margins are not possible. Therefore, other treatments such as chemotherapy and radiotherapy have been considered to achieve complete remission $[1,9,10]$. Surgical excision typically requires the animal to undergo general anesthesia. This procedure is both costly and can be high risk in certain geriatric patients. In these cases, the associated morbidity, risk and cost severely limits the treatment options for MCT's, which can result in elected non-treatment of the disease.

An alternative treatment option for cutaneous MCT is Cryoablation (CA). CA is the use of ultra-low temperatures to provide targeted freezing and subsequent destruction of cancerous or non-cancerous tissues. As a minimally invasive modality with less side effects than radiation and chemotherapy, CA is an attractive option for the treatment of solid tumors [11-13]. Cryosurgical techniques include ultrasound guided imaging to visualize ice ball formation as well as temperature monitoring by the placement of multiple thermocouples [1315]. CA has been applied with a high degree of success in the treatment of skin, prostate, renal, liver, breast, and bone cancers, among others in both humans and animals [16-23]. To this end, several reports have demonstrated CA is as effective or superior to other cancer treatment options including surgery, radiotherapy and chemotherapy [12,24-26]. In addition to being an effective cancer therapy, CA has the benefit of low incidence of postoperative morbidity, low levels of pain, and is often utilized as a outpatient surgical approach $[12,24,25]$. CA also offers the benefit of being a minimally invasive procedure thereby reducing and in some cases eliminating the need for general anesthesia $[13,14]$

Cryosurgery also has a long but limited history of application in the veterinary setting. Some of the first reports of CA in small animals were in the treatment of dermatological conditions in dogs and cats [27-29]. Over time, the range of CA treated neoplasms has expanded to include less accessible organs. CA has been reported in numerous cases as early as 1971 for the treatment of laryngeal neoplasms [30-32]. Additionally, cardiac CA procedures have been performed to treat canine arrhythmias [33], as well as to test the feasibility of epicardial ablation [34]. One study performed on canine renal neoplasms determined the procedure was a safe and feasible treatment option [35] and a case report described successful CA of a canine intranasal tumor [36]. These studies illustrate the use of cryosurgery as a possible treatment option for a variety of disease states.

The reported benefits and effectiveness of CA in both the veterinary and human cancer therapy arenas suggests that CA may represent a viable option for MCT. While a potential option, there is little information in the primary literature as to the effectiveness and response of MCT's to CA. Numerous studies have detailed the effects of freezing in various cell systems demonstrating a differential response to similar freezing insults. Cell death due to freezing is not only a consequence of freeze rupture, but is also related to differential freeze-induced cell stress response which is believed to dictate therapeutic outcome $[15,26,37]$. Studies have also demonstrated that different molecular dispositions (sub-types) of the same cancer tissue type can respond differently CA [38-40]. We have published studies using numerous cell models investigating this phenomenon $[12,26,40]$. For instance, Snyder, et al., have shown that breast cancer cells tolerate freezing to $-15^{\circ} \mathrm{C}$, whereas cardiac cells can withstand $-30^{\circ} \mathrm{C}[41,42]$. Other studies have demonstrated prostate cancer cells tolerate $-40^{\circ} \mathrm{C}$ to $-80^{\circ} \mathrm{C}[12,43,44]$. Studies have also established the translatability of in vitro data to clinical outcome and protocol establishment. For example, in vitro studies by Gage, et al.. [12, $13,45]$, led to the clinical target of $-40^{\circ} \mathrm{C}$ for prostate cancer. Studies by Snyder, et al., [41] and others [46], established $-30^{\circ} \mathrm{C}$ as the target for cardiac ablation. More recently, in vitro cell and tissue engineered model studies proved critical to the development of the percutaneous SCN system for prostate cancer $[47,48]$. Given the potential of CA, we conducted a series of cellular and molecular based analyses of mast cells following exposure to sub-freezing temperatures using the $\mathrm{C} 2$ cell line in order to gain an understanding of MCT cell response to CA. The C2 mast cell line was derived from a canine with end-stage illness after multiple metastases were observed and thereby represents an aggressive and advanced form of MCT cancer [49]. The temperature range of $-5^{\circ} \mathrm{C}$ to $-25^{\circ} \mathrm{C}$ was selected for investigation as it represents the reported transitional temperature range between complete cell death and survival in a number of cancers $[11,13,15,50,51]$. We hypothesized that delivery of an effective freeze dose (temperature and time) would result in complete $\mathrm{C} 2$ cell destruction. Further, we hypothesized that both apoptotic and necrotic pathways are activated following exposure to mild sub-freezing temperatures and that this molecular signaling plays a critical role in the extent of cell death.

\section{Materials and methods}

\section{Cell culture}

The C2 canine mastocytoma cell line was obtained from Dr. J. Wakshlag (Cornell University, Ithaca, NY, USA). Cultures were maintained in Falcon T-75 flasks at $37^{\circ} \mathrm{C} / 5 \% \mathrm{CO}_{2}$ in $\mathrm{C} 2$ complete media (RPMI-1640 (Caisson Labs, North Logan, UT, USA) with $10 \%$ fetal bovine serum (Caisson Labs), $1 \%$ penicillin/ streptomycin (Mediatech, Manassas, VA, USA), 1\% sodium pyruvate (Lonza, Walkersville, MD, USA), and $0.5 \%$ 2-ME (6ouM final concentration) (Sigma-Aldrich, St. Louis, MO, USA)), exchanged every 2 days. Experimental subcultures were plated into 96 well strip well plates (Corning, Lowell, MA, USA) at $8 \times 10^{3}$ cells per well or $35 \mathrm{~mm}$ dishes (BD) at $5 \times 10^{5}$ cells per dish 2 days prior to experimentation to allow for the formation of a contiguous cell monolayer.

\section{Freezing protocol}

Costar strips (Corning) with $75 \mu$ l medium per well or $35 \mathrm{~mm}$ 
Falcon dishes with $1.5 \mathrm{ml}$ medium per dish were placed on a precooled block within a circulating temperature-controlled bath at a preset temperature. Samples were frozen to temperatures of $-5,-10,-15,-20$ or $-25^{\circ} \mathrm{C}$. Sample temperature was monitored with a type T thermocouple (Omega, Stamford, CT, USA) and ice nucleation was initiated by liquid nitrogen vapor (crystallized water vapor) when samples reached $-2^{\circ} \mathrm{C}\left( \pm 1^{\circ} \mathrm{C}\right)$. Samples were held for 3,5 , or $10 \mathrm{~min}$ and then allowed to thaw at room temperature (10min) before return to normothermic culture $\left(37^{\circ} \mathrm{C}\right)$ to allow for system recovery and downstream assessment.

\section{Cell viability}

Sample viability was assessed post-thaw using the metabolic activity assay alamarBlue (Invitrogen, Carlsbad, CA, USA), diluted 1:20 in Hanks balanced salt solution (Mediatech). Media was aspirated and replaced with $100 \mu \mathrm{l}$ per well alamarBlue for $1 \mathrm{~h}$ incubation at $37^{\circ} \mathrm{C}$, and subsequently analyzed with a Tecan SPECTRAFluorPlus plate reader (TECAN Austria GmbH, Grödig, Austria) at excitation $\lambda=530 \mathrm{~nm}$ and emission $\lambda=590 \mathrm{~nm}$. Following assessment, fresh media was replaced and samples were returned to $37^{\circ} \mathrm{C}$. Assessment was repeated daily over a 3 days recovery period.

\section{Caspase inhibition assay}

Pan caspase inhibitor VI (EMD Millipore, Billerica, MA, USA) was reconstituted in dimethyl sulfoxide at a concentration of $10 \mathrm{mM}$ and diluted to a final concentration of $10 \mu \mathrm{M}$ in culture media prior to use. Inhibitor was applied in fresh medium to $\mathrm{C} 2$ subcultures in costar plates and kept at $37^{\circ} \mathrm{C}$ for 30 minutes prior to freeze exposure.

\section{Fluorescence microscopy}

Samples were frozen as described and then fluorescence imaging was conducted at $1,4,8$ and $24 \mathrm{~h}$ post-freeze. Prior to imaging, samples were labeled with tri-stain fluorescent probes Hoechst (living cells, $0.06 \mu \mathrm{g} / \mu \mathrm{l}$ ), propidium iodide (necrotic cells, $0.007 \mu \mathrm{g} / \mu \mathrm{l}$ ), and YO-PRO-1 (apoptotic cells, $0.8 \mu \mathrm{M})$ (Molecular Probes, Invitrogen, Eugene, OR, USA) to allow for identification of living, necrotic, and apoptotic populations within the sample. Samples were incubated for 15min in the dark before visualization using Zeiss Axiovert software (Carl Zeiss Microimaging, Thornwood, NY, USA) at $20 \times$ magnification.

\section{Immunoblotting}

Total protein was isolated temporally at 1, 4, 8 and 24hours post-freeze using radioimmunoprecipitation assay (RIPA) buffer with Halt protease inhibitor cocktail (Thermo Scientific, Rockford, IL, USA). Cell lysates were centrifuged for 15minutes at 13,000 rpm to collect the supernatant protein. Protein levels were quantified using a bicinchoninic acid protein assay kit (Pierce, Thermo Scientific). Equal amounts of protein $(45 \mu \mathrm{g})$ were separated on $12 \%$ polyacrylamide gels for $50 \mathrm{~min}$ at $200 \mathrm{~V}$ and then transferred to polyvinylidene difluoride membranes using a semi-dry transfer system (Bio-Rad, Hercules, CA, USA) for $30 \mathrm{~min}$ at $15 \mathrm{~V}$. Membranes were blocked with a non-animal protein buffer (G-Biosciences, Maryland Heights, MO, USA) diluted 1:1 with Tris-buffered saline and 0.1\% Tween-20 for $1 \mathrm{~h}$ at room temperature. Membranes were exposed to primary antibody overnight at $4{ }^{\circ} \mathrm{C}$ in a humidity chamber. Primary antibodies were validated by the manufacturer for canine reactivity and include: phospho-Akt (1:500, Cell Signaling Technology, Danvers, MA, USA); Bcl2 (1:250, BD Transduction Laboratories, Franklin Lakes, NJ, USA); PARP (1:500, BD), Bax (1:500, BD), and $\alpha$-tubulin (1:2000, abcam, Cambridge, MA, USA). Antibodies were diluted in a 1:2 solution of nonanimal protein buffer and Tris-buffered saline with $0.1 \%$ Tween-20. Membranes were then washed (three washes at ten minutes each with agitation) in Tris-buffered saline with $0.1 \%$ Tween-20 prior to $1 \mathrm{~h}$ room temperature secondary antibody hybridization in a 1:2 dilution of non-animal protein buffer in Tris-buffered saline with $0.1 \%$ Tween-20 with goat anti-rabbit-HRP (1:10,000, Pierce) or goat anti-mouse-HRP (1:10,000, Pierce) and StrepTactin-HRP (1:40,000, Bio-Rad) for molecular weight marker visualization. Membranes were then washed as described above before detection using the LumiGLO/Peroxidase chemiluminescent detection kit (CST) on a FujiFilm LAS-3000 system (FujiFilm, Edison, NJ, USA). Molecular weight was confirmed by migration of the western C-HRP protein marker (Bio-Rad).

\section{Freezing of mast cell tumor tissue}

A primary canine mast cell tumor biopsy was obtained via a fine needle aspirate procedure (Dr. A. Beaulieu, DVM, Dickin Memorial Animal Hospital, Johnson City, NY, USA). Following harvest, the biopsy was immediately placed in Viaspan and held at $4{ }^{\circ} \mathrm{C}$ for $24 \mathrm{~h}$. Prior to experimentation, tissue was rinsed with a $1 \times$ phosphate-buffered saline (PBS, Mediatech) solution, sectioned and weighed. The control section was cultured with $\mathrm{C} 2$ complete media at $37^{\circ} \mathrm{C}$. The experimental tissue samples were placed into a thin-walled PCR tube with $500 \mu \mathrm{L}$ media and then subjected to a short (2m30s) freeze exposure to $-20^{\circ} \mathrm{C}\left( \pm 1^{\circ} \mathrm{C}\right)$. Temperature was monitored with a type T thermocouple (Omega, Stamford, CT, USA) placed in the center of a representative the tissue sample. Following freeze exposure, the samples were placed into ex vivo tissue culture and assessed for viability at 1 and $24 \mathrm{~h}$ post freeze. To assess viability, $1 \mathrm{~mL}$ alamarBlue diluted 1:20 in HBSS was placed on each tissue section for $1 \mathrm{~h}$; the alamarBlue solution was aspirated into wells of a 96-well plate for spectrophotometer analysis and the tissue samples were returned to culture with fresh medium. Fluorescent units were then compared to nontreated tissue samples to determine percent viability.

\section{Data analysis}

Experiments were repeated a minimum of three times with an intra-experimental replicate of 7 samples/condition. Statistical significance $(\mathrm{p}<0.01)$ was determined by one way ANOVA using Excel. Viability is expressed as percent of control. Calculations of standard error mean $( \pm S E M)$ was conducted using the 21 wells from combined experiments. Immunoblot protein bands were quantified with background values subtracted using densitometric analysis on Fuji Film Multi Gauge software V2.3 (Fuji Film). 


\section{Results}

\section{Impact of temperature and hold time on C2 survival}

The C2 canine mastocytoma cell line was exposed to temperatures ranging from $-5^{\circ} \mathrm{C}$ to $-25^{\circ} \mathrm{C}$ and cell viability was assessed at $24 \mathrm{~h}$ post-thaw (Figure 1). Regardless of exposure time $\left(3,5\right.$, or 10minutes), samples exposed to $-5^{\circ} \mathrm{C}$ and $-10^{\circ} \mathrm{C}$ demonstrated no significant cell loss compared to controls $\left(<5 \% ;-5^{\circ} \mathrm{C} 5 \min p=0.62,-5^{\circ} \mathrm{C} 10 \mathrm{~min} p=0.05,-10^{\circ} \mathrm{C}\right.$ $\left.5 \mathrm{~min} p=0.37,-10^{\circ} \mathrm{C} 10 \mathrm{~min} p=0.04\right)$. Exposure to $-15^{\circ} \mathrm{C}$ resulted in a significant increase in cell death, $24 \%( \pm 1.8), 57 \%( \pm 2.0)$, and $71 \%( \pm 1.14)$ cell loss, when held for 3,5 , or 10minutes, respectively (Figure 1 ( $3 \mathrm{~min}$ data not shown)) ( $p<0.001$ for all samples). All samples, however, were found to recover to control levels by day 3 post-thaw. Exposure to $-20^{\circ} \mathrm{C}$ resulted in a further increase in cell death in a time-dependent manner. Following exposure to $-20^{\circ} \mathrm{C}$ cell survival was $12 \%( \pm 1.4)$ (3min), $11.9 \%( \pm 0.9)(5 \mathrm{~min})$, and $5.0 \%( \pm 0.2)(10 \mathrm{~min})$ of untreated controls following 3, 5 or 10minute holds (respectively) at $24 \mathrm{~h}$ post-freeze. While a low level of cell survival was noted following exposure to $-20^{\circ} \mathrm{C}(5-12 \%)$, no re-growth was noted in any of the $-20^{\circ} \mathrm{C}$ samples over the 3 day recovery period. Exposure to $-25^{\circ} \mathrm{C}$ resulted in complete cell death regardless of the hold time. These data indicated that exposure time is a factor in $\mathrm{C} 2$ cell ablation at temperatures between $-15^{\circ} \mathrm{C}$ and $-20^{\circ} \mathrm{C}$. However, when exposed to temperatures of $\leq-25^{\circ} \mathrm{C}$, complete ablation was achieved regardless of the exposure time.

\section{Fluorescence microscopy correlates apoptosis and ne- crosis post-freeze}

To visually assess the temporal regulation of cell death, fluorescence microscopy analysis was conducted using probes specific for apoptosis (YO-Pro-1) or necrosis (Propidium Iodide (PI) at $1,4,8$, and $24 \mathrm{~h}$ post-thaw following exposure to $-10^{\circ} \mathrm{C}$, $-15^{\circ} \mathrm{C}$, and $-20^{\circ} \mathrm{C}$. The analysis confirmed the relative level of cell death (apoptosis and necrosis) and viability at $24 \mathrm{~h}$ within each population as was found in the viability studies (Figure 2). Analysis at $1 \mathrm{~h}$ following a $-10^{\circ} \mathrm{C}$ freeze revealed an increase in the levels of apoptosis/necrosis over that of untreated controls. Continued presence of apoptotic and necrotic populations was observed $4 \mathrm{~h}$ and $8 \mathrm{~h}$ post-freeze. Yet by $24 \mathrm{~h}$ post-freeze, $-10^{\circ} \mathrm{C}$ samples did not differ significantly from controls. Following freezing to $-15^{\circ} \mathrm{C}$ a significant population of apoptotic and necrotic cells were apparent as early as $1 \mathrm{~h}$ post-freeze. A continued increase in both populations was observed at $4 \mathrm{~h}$ and $8 \mathrm{~h}$ post-freeze resulting in a significant decline in viability at 24 hours post-freeze. Samples exposed to $-20^{\circ} \mathrm{C}$ also revealed an even greater level of positive staining for apoptosis and necrosis at 1, 4 and 8hours post-freeze resulting in $<10 \%$ survival at 24 hours, which was consistent with the metabolic activity assessment. Interestingly, the levels of cell death were found to peak at 8 hours post-thaw in both the $-20^{\circ} \mathrm{C}$ and $-15^{\circ} \mathrm{C}$ samples illustrating the involvement of a delayed cell death response.

\section{Molecular analysis of relevant proteins}

With the identification of a delayed cell death response

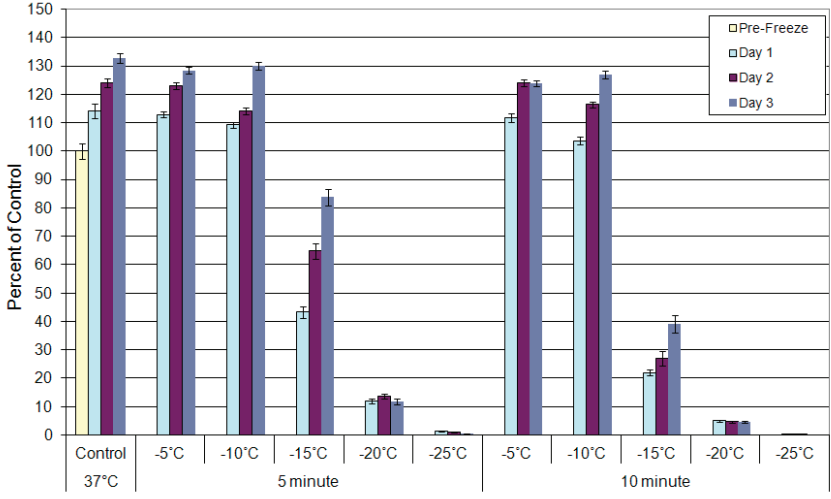

Figure 1: Assessment of C2 canine mastocytoma cell viability following freezing. $\mathrm{C} 2$ cultures were exposed to a 5 or 10 minute cooling regime yielding the nadir temperatures of $-5^{\circ} \mathrm{C},-10^{\circ} \mathrm{C},-15^{\circ} \mathrm{C},-20^{\circ} \mathrm{C}$, or $-25^{\circ} \mathrm{C}$. Following thawing, sample viability (metabolic activity) was assessed at $24 \mathrm{~h}, 48$ and $72 \mathrm{~h}$ post-freeze and compared to a pre-freeze controls. Results indicate that following freezing to $-25^{\circ} \mathrm{C}$ there was complete $\mathrm{C} 2$ cell destruction.

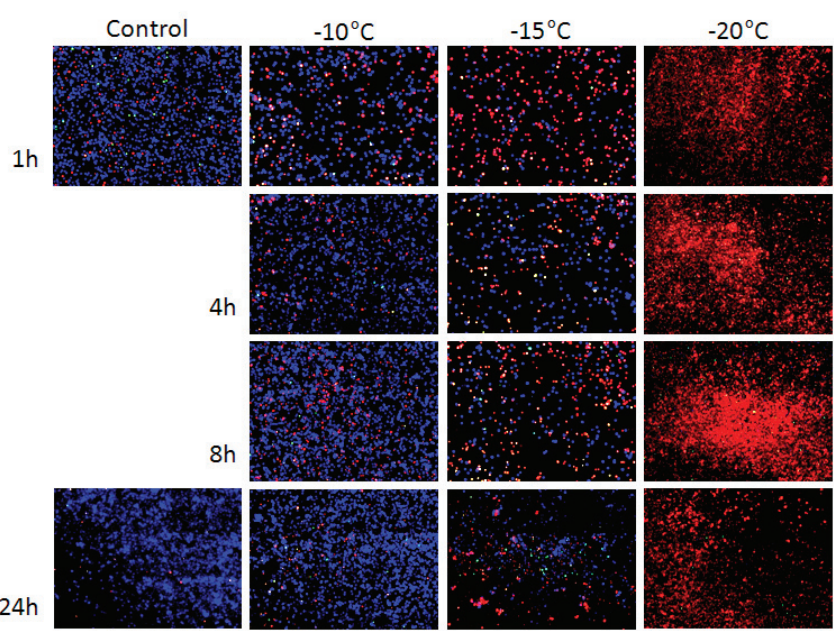

Figure 2: Fluorescence microscopy of $\mathrm{C} 2$ samples following freezing to $-10^{\circ} \mathrm{C}$ $-15^{\circ} \mathrm{C}$, or $-20^{\circ} \mathrm{C}$. Samples were stained with Hoechst 33342 (blue, viable cells), Propidium iodide (red, necrotic cells), and Yo-Pro-1 (green, apoptotic cells) at the indicated time points following a 5 minute freeze event. Results indicate the onset of apoptosis and necrosis following exposure to $-15^{\circ} \mathrm{C}$ as early as $1 \mathrm{~h}$ and continue throughout the $24 \mathrm{~h}$ assessment period. Freezing to $-20^{\circ} \mathrm{C}$ yielded almost exclusively necrotic death

(apoptotic and necrotic activity) via fluorescence microscopy, temporal (1, 4, 8 and 24hours) analysis of cell stress protein levels following freezing at $-10^{\circ} \mathrm{C}$ and $-15^{\circ} \mathrm{C}$ was conducted via western blotting (Figure 3). Protein analyses revealed reductions in the anti-apoptotic protein Bcl-2 levels following freezing when compared to controls. The greatest decrease in Bcl-2 levels was seen within 1hour following freezing to $-10^{\circ} \mathrm{C}$ and $-15^{\circ} \mathrm{C}$ ( 7 fold and 13 fold reductions, respectively; Table 1). Analysis of the pro-apoptotic Bax protein revealed no significant changes following freezing (data not shown). This was not unexpected, as it is generally not the amount of Bax protein, but rather the translocation of Bax from the cytosol to mitochondrial pores that initiates mitochondrial mediated apoptosis. Analysis of the canonical pro-survival protein Akt (protein kinase B) revealed a decrease in phosphorylation and subsequent activation of Akt following freeze exposure. The greatest decrease in phosphorylated AKT (pAKT) was noted 


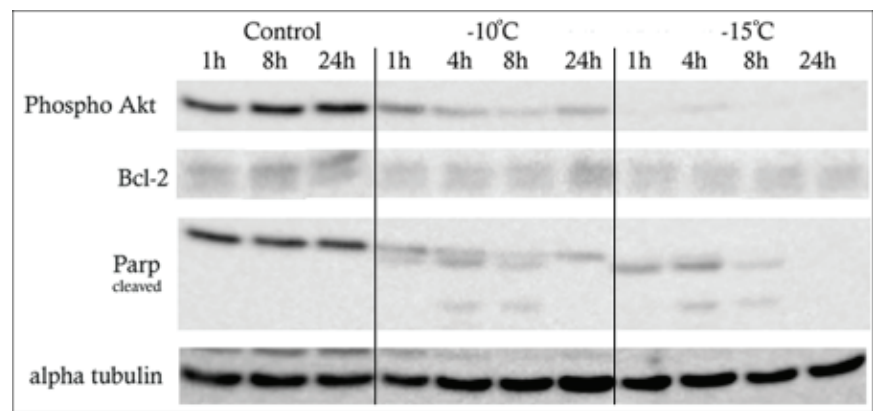

Figure 3: Immunoblot analysis of cellular proteins following freezing to $-10^{\circ} \mathrm{C}$ or $-15^{\circ} \mathrm{C}$. Samples were evaluated for alterations in phospho-Akt, Bcl-2, PARP and a-tubulin (loading control) temporally following freezing. A decrease in phosphorylated Akt (pAKT) was observed following freezing to $-10^{\circ} \mathrm{C}$ and was found to be even greater following exposure to $-15^{\circ} \mathrm{C}$. Alterations in $\mathrm{Bcl}-2$ and PARP (poly-ADP-ribose) protein levels were also observed at 4 and 8 hours post freeze suggesting the activation of a delayed mitochondrial cell death signaling response.

Table 1: Densitometric analysis of immunoblots. Values were obtained using Fuji Film MultiGauge software V 2.3. Background values were subtracted from each band prior to comparative analysis.

\begin{tabular}{|c|c|c|c|c|c|c|c|c|c|c|c|}
\hline \multicolumn{3}{|c|}{ Control } & \multicolumn{4}{|c|}{$-\mathbf{1 0}^{\circ} \mathbf{C}$} & \multicolumn{4}{|c|}{$\mathbf{- 1 5}^{\circ} \mathbf{C}$} \\
\hline & $\mathbf{1 h}$ & $\mathbf{8 h}$ & $\mathbf{2 4 h}$ & $\mathbf{1 h}$ & $\mathbf{4 h}$ & $\mathbf{8 h}$ & $\mathbf{2 4 h}$ & $\mathbf{1 h}$ & $\mathbf{4 h}$ & $\mathbf{8 h}$ & $\mathbf{2 4 h}$ \\
\hline P-AKT & 22.5 & 28.5 & 29.3 & 11.1 & 5.2 & 1.7 & 4.9 & 0.95 & 0.06 & 0.49 & 0.93 \\
\hline Bcl2 & 11.6 & 12.2 & 13.5 & 9.1 & 9.1 & 8.7 & 8.6 & 9.1 & 8.2 & 9.1 & 7.8 \\
\hline Parp full & 15.1 & 21.1 & 15.3 & 11.5 & 8.5 & 5.6 & 7.2 & 8.06 & 4.8 & 1.4 & 1.3 \\
\hline $\begin{array}{c}\text { Parp } \\
\text { Cleaved }\end{array}$ & 0 & 0 & 0 & 4.6 & 12.8 & 13.2 & 3.5 & 18.7 & 23.5 & 14.7 & 5.3 \\
\hline
\end{tabular}

following exposure to $-15^{\circ} \mathrm{C}$. Compared to controls, pAKT levels $-10^{\circ} \mathrm{C}$ samples were reduced by two fold at $1 \mathrm{~h}$ post-freeze. This reduction increased to 4.5 fold at $4 \mathrm{~h}$, and 13.7 fold at $8 \mathrm{~h}$ postfreeze. By $24 \mathrm{~h}$ post freeze, pAkt protein levels began to recover yielding levels similar to the $4 \mathrm{~h}$ post freeze sample. Analysis of $-15^{\circ} \mathrm{C}$ samples revealed virtually no phosphorylated Akt at any time point assessed. This may indicate that freeze stress may prevent the initiation of survival signaling via AKT, thereby augmenting cell death. Western blot analysis of PARP (polyADP ribose polymerase), a protein activated during DNA repair and one of the first targets of the apoptotic "executioner" enzyme caspase- 3 , revealed proteolytic cleavage products at 4 and 8hours following a $-10^{\circ} \mathrm{C}$ freeze. PARP analysis from $-15^{\circ} \mathrm{C}$ samples revealed an increase in cleavage products at 4 and 8hours compared to $-10^{\circ} \mathrm{C}$ samples and complete degradation of PARP cleavage products by 24 hours. Comparing $-10^{\circ} \mathrm{C}$ and $-15^{\circ} \mathrm{C}$ samples, PARP cleavage was found to be greater and quicker in the $-15^{\circ} \mathrm{C}$ samples peaking at 4 hours whereas $-10^{\circ} \mathrm{C}$ samples peaked at $8 \mathrm{~h}$ hours post-thaw (Table 1 ).

\section{Inhibition of caspases decreases the contribution of apoptotic cell death processes post-freeze}

With the identification of a delayed cell death and alterations in apoptosis related proteins following freezing, assessment of the impact of caspase inhibition on cell survival following freezing was conducted. This analysis was performed as a first step in quantifying the level of apoptotic involvement in cell death following freezing. $\mathrm{C} 2$ cells were pre-treated with a pan caspase inhibitor for 30 minutes prior to freeze to $-10^{\circ} \mathrm{C},-15^{\circ} \mathrm{C}$ and $-20^{\circ} \mathrm{C}$. As with freezing only samples, exposure to $-10^{\circ} \mathrm{C}$ in the presence of caspase inhibitors did not significantly impact cell viability (Figure 4). Exposure to $-15^{\circ} \mathrm{C}$ in the presence of caspase inhibition resulted in a $13.6 \%$ improvement in overall survival (26.6\% increase) compared to non-inhibited $-15^{\circ} \mathrm{C}$ samples $(64.42 \%( \pm 1.6)$ vs. $50.84 \%( \pm 1.7), p<0.001$ (Figure 4$)$ ). These results indicated that the apoptotic caspases signaling contributed to cell death following a $-15^{\circ} \mathrm{C}$ freeze. When samples were exposed to $-20^{\circ} \mathrm{C}$ in the presence of caspase inhibition no significant change in cell survival was noted.

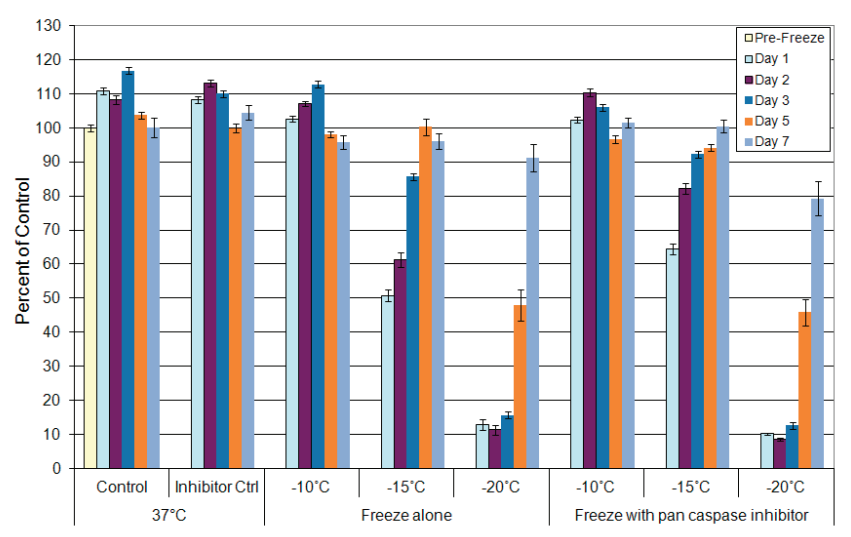

Figure 4: Assessment of the impact of caspase inhibition on C2 survival following freezing. Samples were treated for 30 mins with pan caspase inhibitor and then exposed to a 5 minute freeze to $-10^{\circ} \mathrm{C},-15^{\circ} \mathrm{C}$, or $-20^{\circ} \mathrm{C}$. Caspase inhibition in samples exposed to $-15^{\circ} \mathrm{C}$ resulted in an increase in cell survival compared to noninhibited $-15^{\circ} \mathrm{C}$ samples, indicating apoptosis may play a significant role in $\mathrm{C} 2$ death following freezing.

\section{Primary mast cell tumor isolate response to low tempe- rature exposure}

In addition to the in vitro $\mathrm{C} 2$ studies, analysis of a primary grade 2 , stage 2 canine MCT tumor sample was conducted. The MCT sample was excised via fine needle aspirate biopsy procedure, sectioned, weighed and then exposed to $-20^{\circ} \mathrm{C}$ (Figure 5A). Following freezing, tissue sections were placed into ex vivo culture and analyzed for tissue viability at 1 and $24 \mathrm{~h}$ post-thaw (Figure $5 \mathrm{~B}$ ). The response of the tissue samples was found to be similar to the $\mathrm{C} 2$ in vitro results. Tissue sample viability at 1hour post-thaw was found to be $40 \%$ of nonfrozen controls. Following $24 \mathrm{~h}$ of recovery, a further decrease in viability to $12 \%$ was observed. While a pilot ex vivo case study, the experimental results were found to correlate well with the in vitro freeze response data obtained with the $\mathrm{C} 2$ cell model following exposure to $-20^{\circ} \mathrm{C}$ for 3 minutes.

\section{Discussion}

CA is an effective cancer treatment modality. However, the application of CA in veterinary medicine has been limited. In this study we investigated the effects of CA on MCT cells in an attempt to characterize MCT cell response to freezing, as well as identify the critical target temperature necessary to achieve total cell destruction. The data from this study demonstrated that CA was effective at destroying MCT cells when temperatures 


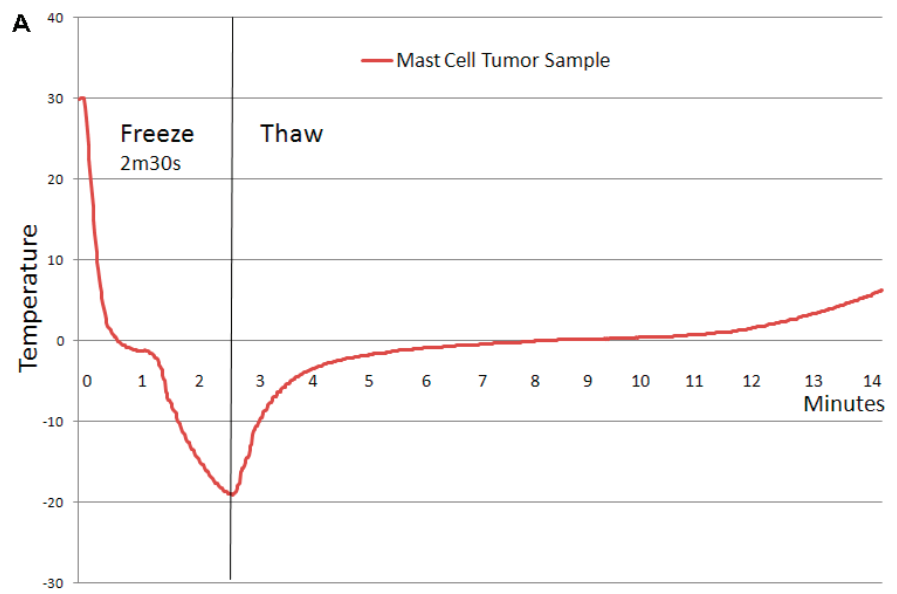

B

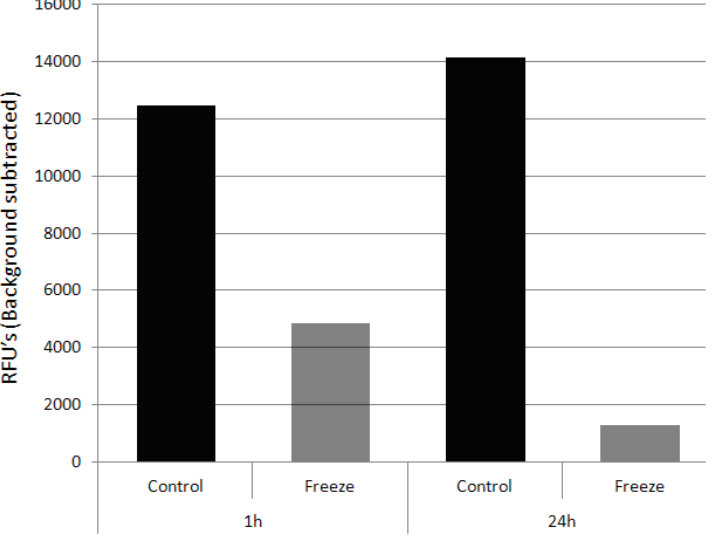

Figure 5: Responses of ex-vivo MCT tissue to freezing to $-20^{\circ} \mathrm{C}$. A) Thermal profile of the freeze event. The freeze/thaw interval was monitored on a type $\mathrm{T}$ thermocouple (Omega). B) Viability assessment of MCT samples following freeze. Assessment of sample viability at $1 \mathrm{~h}$ and $24 \mathrm{~h}$ post freeze revealed that samples frozen to $-20^{\circ} \mathrm{C}$ yielded $24 \mathrm{~h}$ viability (metabolic activity) of $12 \%$ that of non-frozen controls.

of $-25^{\circ} \mathrm{C}$ and lower were achieved regardless of the hold time. The data also demonstrate that when temperatures $\geq-20^{\circ} \mathrm{C}$ were applied the exposure time (hold time) was an important factor. The impact of freezing to $<-20^{\circ} \mathrm{C}$ was confirmed in both the in vitro cell model and pilot ex vivo MCT tissue evaluations. These data correlate well with previous reports from our laboratory on CA in cell systems such as prostate and renal cancer [39,52], establishing that both the nadir temperature and time at temperature play a role in overall outcome.

When performing solid tumor cryosurgery, the temperature typically reached at the center of a cryogenic lesion ranges between $-80^{\circ} \mathrm{C}$ and $-180^{\circ} \mathrm{C}[11,47,50,51]$. Extending radially from the center of the cryolesion, temperatures increase until the edge of the frozen mass, where temperatures are $0^{\circ} \mathrm{C}$, nominally (Figure 6). The corresponding isothermal gradient (temperature gradient profile) within the frozen mass varies depending on application time, freeze repetition, and cryogen utilized $[11,47,50,51]$. As such, it is important to understand the characteristics of the cancer cell response to the range of temperatures associated with a cryogenic lesion. Our studies focused on the warmer sub-freezing temperatures associated with the periphery (outer edge) of the freeze lesion, as it is generally accepted that temperatures below $-40^{\circ} \mathrm{C}$ result in complete cancer cell lysis through physical ice rupture $[12,13]$. The thermal range of $0^{\circ} \mathrm{C}$ to $-40^{\circ} \mathrm{C}$ is characterized by a region of heterogenic cell responses which includes cell lysis, activation of necrotic and apoptotic pathways, as well as some cell survival $[11,39,45]$. Numerous reports by our group as well as others have demonstrated the transition from complete cell death to complete cell survival within this region $[39,53,54,43]$. Given these facts, it is important to identify the critical lethal temperature for MCT cells as well as understand the molecular responses of this cancer to CA to yield more effective treatment. To this end, the data revealed the minimal lethal temperature for $\mathrm{C} 2 \mathrm{MCT}$ cells was $-25^{\circ} \mathrm{C}$ in vitro whereas the $-15^{\circ} \mathrm{C}$ to $-20^{\circ} \mathrm{C}$ range resulted in a heterogeneous mix of necrotic, apoptotic and surviving cell populations. The data also demonstrated

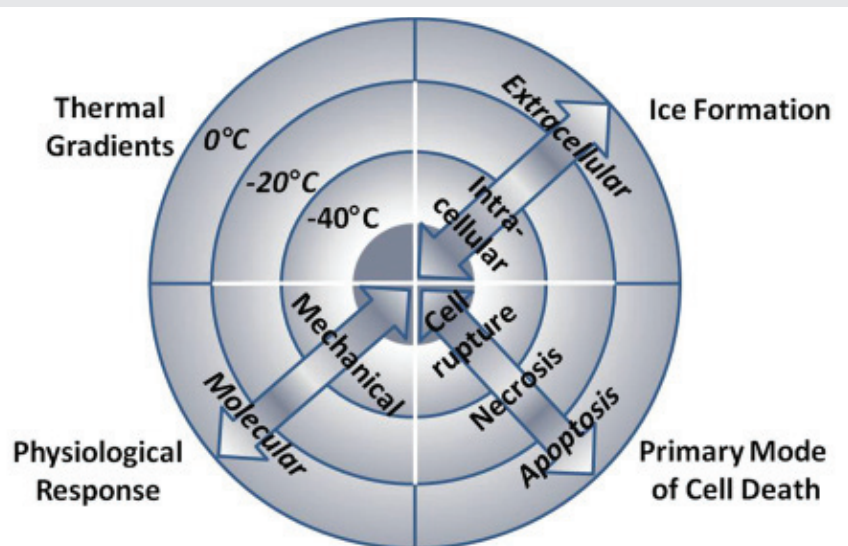

Figure 6: Dynamics of solid tumor cryoablation (modified from Snyder, et al., Mechanisms of Cryoablation in "Cryoablation of Cardiac Arrhythmias", eds. Bredikis and Wilber. Elsevier, Philadelphia, PA, 2011). A selection of the various continuums present in a cryogenic lesion are illustrated, including: isotherms across a thermal gradient generated from a central cryoprobe, types of ice formation, mode of cell death, and physiological response.

that regardless of the exposure temperature, necrosis was the primary mode of cell death. Apoptotic contribution to cell death following freezing has been reported primarily at warmer, sub-freezing temperatures [43,55-57]. In this study, apoptotic involvement was found following exposure to $-15^{\circ} \mathrm{C}$ and was most prominent at 1 and 8 hours post-freeze resulting in the delayed cell death response.

Proteomic analysis confirmed the contribution of a delayed molecular response. The observed loss of Bcl-2 and maintenance of Bax total protein levels (western blot analysis) suggested a shift in the Bcl-2/Bax ratio, thus indicating the activation of the mitochondrial molecular switch signaling the initiation of apoptosis. This is consistent with Robilotto, et al., [55], wherein it was reported that exposure of prostate cancer cells to $-15^{\circ} \mathrm{C}$ results in the activation of mitochondrial based apoptosis whereas exposure to temperatures of $\leq-30^{\circ} \mathrm{C}$ results in the initiation of membrane mediated apoptosis. The observed decrease in pAkt following freezing further suggests 
that the loss of pro-survival signaling contributes significantly to the overall level of cell death. Combined with the observed increases in PARP cleavage and Caspase activation, the molecular data suggest that multiple cell death pathways are involved in low temperature death responses in mast cells.

Given that the incidence of MCT's is largely breed specific, a genetic basis for tumor development is likely. Numerous studies have implicated the c-kit gene product, an integral membrane receptor tyrosine kinase (RTK), in MCT signaling [58-61]. Many mutations in this gene cause the constitutively active form of the receptor, signaling the cell to proliferate even in the absence of its ligand, stem cell factor [58]. As such, c-kit specific small molecule inhibitors have been used with some success. Drug resistance, however, could become an issue in vivo [60]. Previous studies from our laboratory have shown the success of adjuvants used for cryosensitization [37,57,62-65]. These and other studies have detailed the benefit of adjunctive treatment involving CA with the pre-treatment of low-dose chemotherapy, nutraceuticals or other agents in a number of cancers including prostate, breast, lung and liver among others [37,65-77]. In vitro and in vivo studies involving prostate cancer have shown the ability of cryosensitizing adjuvants to elevate the minimal lethal temperature for hormone refractory prostate cancer from $-40^{\circ} \mathrm{C}$ to $-20^{\circ} \mathrm{C}$ via pre-treatment with sub-clinical (non-toxic) doses of 5-fluorocil, taxotere and cisplatin $[65,66,71]$. Other studies have demonstrated that combinatorial approaches using the active nutraceutical calcitriol (vitamin $\mathrm{D}_{3}$ ) can result in the elevation of the minimal lethal temperature for prostate cancer to the -10 to $-15^{\circ} \mathrm{C}$ range $[57,75,76,78]$. Based on these reports coupled with the identification of a delayed molecular cell death response activated following freezing of $\mathrm{C} 2$ cells, the use of adjuvant agents, including chemotherapy and immunotherapy agents as well as RTK inhibitors, in combination with CA is an area that may also provide benefit for treatment of MCT's and as such should be explored in future studies.

In conclusion, the data from this study suggest that CA has the potential to be an effective therapeutic option for the treatment of canine mast cell tumors, both malignant and benign. The findings provide a baseline characterization of the cellular and molecular responses of an MCT cell line to freezing as well as identified $-20^{\circ} \mathrm{C}$ to $-25^{\circ} \mathrm{C}$ as the critical temperature range for complete MCT cell destruction depending on hold time. Complete $\mathrm{C} 2$ cell destruction at $-25^{\circ} \mathrm{C}$ was found regardless of the hold time whereas a hold of 10 minutes was necessary of complete destruction at $-20^{\circ} \mathrm{C}$. Pilot study ex vivo freezing of grade 2, stage 2 MCT tissue correlated with in vitro findings and in combination provide a basis for the further exploration of the use of CA for the treatment of MCT in vivo. The data presented herein suggest that CA may provide a minimally invasive, rapid therapeutic option for treating mast cell tumors. As such, additional studies in the application of CA for MCT treatment are warranted.

\section{Acknowledgement}

The authors would like to acknowledge Dr. Alison Beaulieu, DVM, for the surgical removal and staging of MCT tissue, as well as her continued interest and support in our research efforts. The authors would also like to thank Mr. Jordan M. Katz for his contributions to data acquisition for this manuscript.

\section{Declarations}

Funding: This study was supported in part by funding from the National Institutes of Health 1R43CA183265-01 awarded to CPSI Biotech.

Conflicts of interests: JMB, KKS, KLS and RVB are employees of CPSI Biotech. JGB has no competing interests.

Authors' contributions: KLS, JMB and KKS performed all experimental design, experimentation and data analysis for this study. RVB and JGB conducted data and experimental design review and assisted in data interpretation. JMB and KLS prepared the draft manuscript. JMB, KLS, KKS, RVB and JGB provided review and revision input for the manuscript. All authors read and approved the final manuscript.

Availability of data and material: The data that support the findings of this study are available from CPSI Biotech but restrictions apply to the availability of these data, which were used under license for the current study, and so are not publicly available. Data are however available from the authors upon reasonable request and with permission of CPSI Biotech.

\section{References}

1. Withrow SJ, Vail DM (2006) Withrow and MacEwen's Small Animal Clinica Oncology. 4 ed, Saunders. Link: http://bit.ly/20o7g8X

2. Alberts B, Johnson A, Lewis J, Raff M, Roberts K, et al. (2002) Molecula Biology of the Cell. 4 ed. New York, NY, Garland Science. Link: http://bit.ly/37ScaCJ

3. Govier SM (2003) Principles of treatment for mast cell tumors. Clin Tech Small Anim Pract 18: 103-106. Link: http://bit.ly/2v2ff4x

4. Cutaneous Mast Cell Tumors (2006) In: The Merck Veterinary Manual, 9th edn., MA Cynthia M. Kahn, ed., Whitehouse Station, NJ, USA, Merck Sharp \& Dohme Corp., a subsidiary of Merck \& Co., Incs.

5. White CR, Hohenhaus AE, Kelsey J, Procter-Gray E (2011) Cutaneous MCTs: associations with spay/neuter status, breed, body size, and phylogenetic cluster. J Am Anim Hosp Assoc 47: 210-216. Link: http://bit.ly/39116Dr

6. Dobson JM, Scase TJ (2007) Advances in the diagnosis and management of cutaneous mast cell tumours in dogs. J Small Anim Pract 48: 424-431. Link: http://bit.ly/2S9u7WS

7. Peters JA (1969) Canine mastocytoma: excess risk as related to ancestry. $J$ Natl Cancer Inst 42: 435-443. Link: http://bit.ly/2SgVcHN

8. Welle MM, Bley CR, Howard J, Rufenacht S (2008) Canine mast cell tumours: a review of the pathogenesis, clinical features, pathology and treatment. Vet Dermatol 19: 321-339. Link: http://bit.ly/36UiTuO

9. Mayer MN (2006) Radiation therapy for canine mast cell tumors. Can Vet J 47 263-265. Link: http://bit.ly/393ZRUd

10. Stanclift RM, Gilson SD (2008) Evaluation of neoadjuvant prednisone administration and surgical excision in treatment of cutaneous mast cell tumors in dogs. J Am Vet Med Assoc 232: 53-62. Link: http://bit.ly/3b8fFql

11. Baust JG, Snyder KK, Santucci KL, Robilotto AT, Van Buskirk RG, et al. (2019) 
Cryoablation: physical and molecular basis with putative immunological consequences. Int J Hyperthermia 36: 10-16. Link: http://bit.ly/3b5si5P

12. Gage AA, Baust JG (2004) Cryosurgery for tumors - a clinical overview. Technol Cancer Res Treat 3: 187-199. Link: http://bit.ly/2u60loG

13. Baust JG, Gage AA (2004) Progress toward optimization of cryosurgery. Technol Cancer Res Treat 3: 95-101. Link: http://bit.ly/2GLiOKi

14. Baust JG, Gage AA, Ma H, Zhang CM (1997) Minimally invasive cryosurgerytechnological advances. Cryobiology 34: 373-384. Link: http://bit.ly/2tn77v6

15. Baust JG, Gage AA, Klossner D, Clarke D, Miller R, et al. (2007) Issues critica to the successful application of cryosurgical ablation of the prostate. Technol Cancer Res Treat 6: 97-109. Link: http://bit.ly/20oaY2f

16. Lin $\mathrm{CH}$, Moinzadeh A, Ramani AP, Gill IS (2004) Histopathologic confirmation of complete cancer-cell kill in excised specimens after renal cryotherapy. Urology 64: 590. Link: http://bit.ly/2Si1qXI

17. Johnson DB, Nakada SY (2003) Cryoablation of renal and prostate tumors. $J$ Endourol 17: 627-632. Link: http://bit.ly/38YBBTe

18. Davol PE, Fulmer BR, Rukstalis DB (2006) Long-term results of cryoablation for renal cancer and complex renal masses. Urology 68: 2-6. Link: http://bit.ly/3bazZli

19. Jones JS, Rewcastle JC (2008) Primary cryoablation for Gleason 8, 9, or 10 localized prostate cancer: Biochemical and local control outcomes from the Cryo OnLine database registry. Indian J Urol 24: 490-493. Link: http://bit.ly/3948myG

20. Littrup PJ, Jallad B, Chandiwala-Mody P, D'Agostini M, Adam BA, et al. (2009) Cryotherapy for breast cancer: a feasibility study without excision. $\mathrm{J}$ Vasc Interv Radiol 20: 1329-13241. Link: http://bit.ly/3baA9PU

21. Masala S, Guglielmi G, Petrella MC, Mastrangeli R, Meschini A, et al. (2011) Percutaneous ablative treatment of metastatic bone tumours: visual analogue scale scores in a short-term series. Singapore Med J 52: 182-189. Link: http://bit.ly/31kkSHz

22. Liang Z, Fei Y, Lizhi N, Jianying Z, Zhikai Z, et al. (2014) Percutaneous cryotherapy for metastatic bladder cancer: experience with 23 patients. Cryobiology 68: 79-83. Link: http://bit.ly/2Uk2c9n

23. Sun L, Zhang W, Liu H, Yuan J, Liu W et al. (2014) Computed tomography imaging-guided percutaneous argon-helium cryoablation of muscle-invasive bladder cancer: initial experience in 32 patients. Cryobiology 69: 318-322 Link: http://bit.ly/2SgXAhJ

24. Cohen JK, Miller RJJ, Ahmed S, Lotz MJ, Baust J (2008) Ten-year biochemical disease control for patients with prostate cancer treated with cryosurgery as primary therapy. Urology 71: 515-518. Link: http://bit.ly/393EhPw

25. Babaian RJ, Donnelly B, Bahn D, Baust JG, Dineen M, et al. (2008) Best practice statement on cryosurgery for the treatment of localized prostate cancer. $J$ Urol 180: 1993-2004. Link: http://bit.ly/2Sd5CrJ

26. Klossner DP, Clarke DM, Baust JM, Van Buskirk RG, Gage AA, et al. (2006) Thermal therapeutic options in the treatment of prostate cancer: Cellular responses to cryosurgery and hyperthermia. Cryobiology 53: 438. Link: http://bit.ly/2uUrDUl

27. Krahwinkel DJ (1980) Cryosurgical treatment of skin diseases. Vet Clin North Am Small Anim Pract 10: 787-801. Link: http://bit.ly/2Ug5yu6

28. Goldstein RS, Hess PW (1977) Cryosurgical treatment of cancer. Vet Clin North Am 7: 51-64.

29. Krahwinkel DJ, Merkley DF, Howard DR (1976) Cryosurgical treatment of cancerous and noncancerous diseases of dogs, horses, and cats. J Am Vet Med Assoc 169: 201-207. Link: http://bit.ly/2GQ2H2Y
30. Strome M (1971) Cryosurgery: the effect on the canine endolaryngeal structures. Laryngoscope 81: 1057-1065. Link: http://bit.ly/2tnfPJN

31. Miller D (1975) Cryosurgery as a modality in the treatment of carcinoma of the larynx. Laryngoscope 85: 1281-1285. Link: http://bit.ly/396rDQ6

32. Mulvaney TJ, Miller D (1976) Endolaryngeal cryosurgery. An improved technique. Arch Otolaryngol 102: 226-229. Link: http://bit.ly/36Rp8Q6

33. Ogawa M, Tan AY, Song J, Kobayashi K, Fishbein MC, et al. (2009) Cryoablation of stellate ganglia and atrial arrhythmia in ambulatory dogs with pacing induced heart failure. Heart Rhythm 6: 1772-1779. Link: http://bit.ly/2H1f6Bv

34. Lustgarten DL, Bell S, Hardin N, Calame J, Spector PS (2005) Safety and efficacy of epicardial cryoablation in a canine model. Heart Rhythm 2: 82-90. Link: http://bit.ly/2Si3Rtk

35. Stephenson RA, King DK, Rohr LR (1996) Renal cryoablation in a canine model. Urology 47: 772-776. Link: http://bit.ly/37U1NhY

36. Murphy SM, Lawrence JA, Schmiedt CW, Davis KW, Lee FT, et al. (2011) Image-guided transnasal cryoablation of a recurrent nasal adenocarcinoma in a dog. J Small Anim Pract 52: 329-333. Link: http://bit.ly/2UIZMXK

37. Clarke DM, Robilotto AT, Van Buskirk RG, Baust JG, Gage AA, et al. (2007) Targeted induction of apoptosis via TRAIL and cryoablation: a novel strategy for the treatment of prostate cancer. Prostate Cancer Prostatic Dis 10: 175 184. Link: http://bit.ly/2SgZD5p

38. Baust JG, Klossner DP, Vanbuskirk RG, Gage AA, Mouraviev V, et al. (2010) Integrin involvement in freeze resistance of androgen-insensitive prostate cancer. Prostate Cancer Prostatic Dis 13:151-161. Link: http://bit.ly/360M9TL

39. Klossner DP, Robilotto AT, Clarke DM, VanBuskirk RG, Baust JM, et al. (2007) Cryosurgical technique: assessment of the fundamental variables using human prostate cancer model systems. Cryobiology 55: 189-199. Link: http://bit.ly/3bbJ03R

40. Hollister WR, Baust JM, Van Buskirk RG, Baust JG (2004) Cellular components of the coronary vasculature exhibit differential sensitivity to low temperature insult. Cell Preservation Technology 1: 269-280. Link: http://bit.ly/2RQIIJ1

41. Snyder KK, Baust JM, Van Buskirk RG, Baust JG (2007) Cardiomyocyte responses to thermal excursions: implications for electrophysiological cardiac mapping. Cell Preservation Technology 5: 116-128. Link: http://bit.ly/2SdgupD

42. Snyder KK, Arsenault DMJ, Baust JM, Van Buskirk RG, Baust JG (2008) 60 Cryotherapy modeling in breast carcinoma cells. Cryobiology 57: 327 . Link: http://bit.ly/394IT9q

43. Hollister WR, Mathew AJ, Baust JG (1998) The effects of freezing on cell viability and mechanisms of cell death in an in vitro human prostate cancer cell line. Mol Urol 2: 13-18.

44. Znati CA, Werts E, Kociban D, Kalnicki S (1998) Variables influencing response of human prostate carcinoma cells to combined radiation and Cryotherapy in vitro. Cryobiology 37: 450-451.

45. Baust JG, Gage AA (2005) The molecular basis of cryosurgery. BJU Int 95 1187-1191. Link: http://bit.ly/20oOsGz

46. Geha AS, Abdelhady K (2008) Current status of the surgical treatment of atria fibrillation. World J Surg 32: 346-349. Link: http://bit.ly/36URBnS

47. Baust JM, Robilotto A, Snyder KK, Santucci K, Stewart J, et al. (2017) Assessment of Cryosurgical Device Performance Using a 3D Tissue-Engineered Cancer Model. Technol Cancer Res Treat. Link: http://bit.ly/3b6x3MF

48. Robilotto AT, Baust JM, Santucci KL, Snyder KK, Van Buskirk RG (2019) Assessment of a novel supercritical nitrogen cryosurgical device using prostate and renal cancer tissue engineered models. Med Devices Diagn Eng (submitted) 5: 1-8. Link: http://bit.ly/20n1tk1 
49. DeVinney R, Gold WM (1990) Establishment of two dog mastocytoma cell lines in continuous culture. Am J Respir Cell Mol Biol 3: 413-420. Link: http://bit.ly/2uhSiua

50. Littrup PJ, Jallad B, Vorugu V, Littrup G, Currier B, et al. (2009) Lethal isotherms of cryoablation in a phantom study: effects of heat load, probe size, and number. J Vasc Interv Radiol 20: 1343-1351. Link: http://bit.ly/36W36LU

51. Shah TT, Arbel U, Foss S, Zachman A, Rodney S, et al. (2016) Modeling Cryotherapy Ice Ball Dimensions and Isotherms in a Novel Gel-based Model to Determine Optimal Cryo-needle Configurations and Settings for Potential Use in Clinical Practice. Urology 91: 234-240. Link: http://bit.ly/37ZQcOw

52. Clarke DM, Robilotto AT, Rhee E, VanBuskirk RG, Baust JG, et al. (2007) Cryoablation of renal cancer: variables involved in freezing-induced cell death Technol Cancer Res Treat 6: 69-79. Link: http://bit.ly/384t0Pb

53. Robilotto AT, Clarke D, Baust JM, Van Buskirk RG, Gage AA, et al. (2007) Development of a tissue engineered human prostate tumor equivalent for use in the evaluation of cryoablative techniques. Technol Cancer Res Treat 6: 81 89. Link: http://bit.ly/2H1khBr

54. Gage AA, Baust JM, Baust JG (2009) Experimental cryosurgery investigations in vivo. Cryobiology 59: 229-243. Link: http://bit.ly/3b2sOBT

55. Robilotto AT, Baust JM, Van Buskirk RG, Gage AA, Baust JG (2013) Temperature-dependent activation of differential apoptotic pathways during cryoablation in a human prostate cancer model. Prostate Cancer Prostatic Dis 16: 41-49. Link: http://bit.ly/2uegVIk

56. Yang WL, Addona T, Nair DG, Qi L, Ravikumar TS (2003) Apoptosis induced by cryo-injury in human colorectal cancer cells is associated with mitochondrial dysfunction. Int J Cancer 103: 360-369. Link: http://bit.ly/2uWuRqo

57. Baust JM, Klossner DP, Robilotto AT, Vanbuskirk RG, Gage AA, et al. (2012) Vitamin $D(3)$ cryosensitization increases prostate cancer susceptibility to cryoablation via mitochondrial-mediated apoptosis and necrosis. BJU Int 109 949-958. Link: http://bit.ly/37RhsyA

58. Edling CE, Hallberg B (2007) c-Kit--a hematopoietic cell essential receptor tyrosine kinase. Int J Biochem Cell Biol 39: 1995-1998. Link: http://bit.ly/2GQIqug

59. Gleixner KV, Rebuzzi L, Mayerhofer M, Gruze A, Hadzijusufovic E, et al (2007) Synergistic antiproliferative effects of KIT tyrosine kinase inhibitors on neoplastic canine mast cells. Exp Hematol 35: 1510-1521. Link: http://bit.ly/20p2I7P

60. Khanna C, Gordon I (2009) Catching cancer by the tail: new perspectives on the use of kinase inhibitors. Clin Cancer Res 15: 3645-3647. Link: http://bit.ly/31inMg3

61. Takeuchi Y, Fujino Y, Watanabe M, Nakagawa T, Ohno K, et al. (2010) Aberrant autophosphorylation of c-Kit receptor in canine mast cell tumor cell lines. Vet Immunol Immunopathol 137: 208-216. Link: http://bit.ly/2ScDhC7

62. Santucci KL, Snyder KK, Baust JM, Van Buskirk RG, Mouraviev V, et al. (2011) Use of 1,25a dihydroxyvitamin D3 as a cryosensitizing agent in a murine prostate cancer model. Prostate Cancer Prostatic Dis 14: 97-104. Link: https://go.nature.com/2u58aQX

63. Baust JM, Klossner DP, Robilotto AT, Van Buskirk RG, Gage AA, et al. (2011) Use of $1,25 a$ dihydroxyvitamin D3 as a cryosensitizing agent in a murine prostate cancer model. Prostate Cancer and Prostatic Diseases 14: 97-104. Link: https://go.nature.com/2u58aQX
64. Clarke DM, Baust JM, Van Buskirk RG, Baust JG (2001) Chemo-cryo combination therapy: an adjunctive model for the treatment of prostate cancer. Cryobiology 42: 274-285. Link: http://bit.ly/2RTFcwv

65. Clarke DM, Baust JM, Van Buskirk RG, Baust JG (2004) Addition of anticancer agents enhances freezing-induced prostate cancer cell death: implications of mitochondrial involvement. Cryobiology 49: 45-61. Link: http://bit.ly/20i6CtF

66. Yuan F, Zhou W, Zhang J, Zhang Z, Zou C, et al. (2008) Anticancer drugs are synergistic with freezing in induction of apoptosis in HCC cells. Cryobiology 57: 60-65. Link: http://bit.ly/38ZEnb5

67. Forest V, Peoc'h M, Ardiet C, Campos L, Guyotat D, et al. (2005) In vivo cryochemotherapy of a human lung cancer model. Cryobiology 51: 92-101. Link: http://bit.ly/36UVv00

68. Forest V, Peoc'h M, Campos L, Guyotat D, Vergnon JM (2006) Benefit of a combined treatment of cryotherapy and chemotherapy on tumour growth and late cryo-induced angiogenesis in a non-small-cell lung cancer model. Lung Cancer 54: 79-86. Link: http://bit.ly/2v0nHBk

69. Ikekawa S, Ishihara K, Tanaka S, Ikeda S (1985) Basic studies of cryochemotherapy in a murine tumor system. Cryobiology 22: 477-483. Link: http://bit.ly/2vGo5p2

70. Jiang J, Goel R, Iftekhar MA, Visaria R, Belcher JD, et al. (2008) Tumor necrosis factor-alpha-induced accentuation in cryoinjury: mechanisms in vitro and in vivo. Mol Cancer Ther 7: 2547-2555. Link: http://bit.ly/3b5LYqn

71. Le Pivert P, Haddad RS, Aller A, Titus K, Doulat J, et al. (2004) Ultrasound guided combined cryoablation and microencapsulated 5-Fluorouracil inhibits growth of human prostate tumors in xenogenic mouse model assessed by luminescence imaging. Technol Cancer Res Treat 3: 135-142. Link: http://bit.ly/3b963Mk

72. Mir LM, Rubinsky B (2002) Treatment of cancer with cryochemotherapy. Br J Cancer 86: 1658-1660. Link: http://bit.ly/2GNJqiy

73. Pham L, Dahiya R, Rubinsky B (1999) An in vivo study of antifreeze protein adjuvant cryosurgery. Cryobiology 38: 169-175. Link: http://bit.ly/36QkQbG

74. Wang CL, Teo KY, Han B (2008) An amino acidic adjuvant to augment cryoinjury of MCF-7 breast cancer cells. Cryobiology 57: 52-59. Link: http://bit.ly/2SgUj1E

75. Kimura M, Rabbani Z, Mouraviev V, Tsivian M, Caso J, et al. (2010) Role of vitamin $\mathrm{D}(3)$ as a sensitizer to cryoablation in a murine prostate cancer model: preliminary in vivo study. Urology 76: 764. e14-e20. Link: http://bit.ly/3b6B181

76. Santucci KL, Baust JM, Snyder KK, Van Buskirk RG, Baust JG (2018) Dose Escalation of Vitamin D3 Yields Similar Cryosurgical Outcome to Single Dose Exposure in a Prostate Cancer Model. Cancer Control 25: 1073274818757418 Link: http://bit.ly/36V0Jc6

77. Baust JG, Bischof JC, Jiang-Hughes S, Polascik TJ, Rukstalis DB, et al. (2015) Re-purposing cryoablation: a combinatorial 'therapy' for the destruction of tissue. Prostate Cancer Prostatic Dis 18: 87-95. Link: http://bit.ly/37TKbTI

78. Santucci KL, Snyder KK, Baust JM, Van Buskirk RG, Mouraviev V, et al. (2011) Use of 1,25alpha dihydroxyvitamin D3 as a cryosensitizing agent in a murine prostate cancer model. Prostate cancer and prostatic diseases 14: 97-104 Link: https://go.nature.com/2u58aQX

Copyright: @ 2020 Santucci KL, et al. This is an open-access article distributed under the terms of the Creative Commons Attribution License, which permits unrestricted use, distribution, and reproduction in any medium, provided the original author and source are credited.

Citation: Santucci KL, Snyder KK, Van Buskirk RG, Baust JG, Baust JM (2020) Characterization of canine mastocytoma cell response to cryoablation. Int J Vet Sci Res 6(1): 005-013. DOI: https://dx.doi.org/10.17352/ijvsr.000047 